\title{
Imre Anikó
}

\section{Minōség és televízió}

\begin{abstract}
Absztrakt
A tanulmány a „minôségi televízió” jelenségét tárgyalja, amely elválaszthatatlan az internetes, streaming platformok elterjedésétôl, és változásokat, reakciókat váltott ki a magyar és tágabban a posztszocialista film- és médiatudományban. A szerzô összehasonlító történelmi kontextusban vizsgálja a „minôségi (televíziózás)” fogalmát. Megkülönbözteti az HBO-féle amerikai és az európai közszolgálati televízió minôségfogalmait, és összeveti ezeket a televízió megítélésével Kelet-Európában, ahol a kritikai és tudományos intézmények a tévét kezdettôl fogva a felvilágosítás, a meggyôzés és a szórakoztatás eszközének tekintették (vagy tekintik továbbra is), mint amely kevés kulturális vagy múvészi értéket hordoz, ellentétben a filmmel, a színházzal és az irodalommal. A globálisan és digitálisan elérhetô „minôségi televízió”, amelyet Kelet-Európában legjobban az HBO Europe drámái példáznak, alapvetôen megváltoztatta a tévé identitását és megitélését világszerte. A régiónkban az a veszély fenyeget, hogy ahelyett, hogy az új, minôségi tévé végre legitimálná a televíziót mint intézményt, valamint annak nézôit és kultúráját, még inkább felerôsíti az idejétmúlt és politikailag korlátozó hierarchiát magas vagy múvészi, valamint alacsony vagy népszerú médiumok és azok képviselôi között. Mindezt máshol az interdiszciplináris televíziós tanulmányok több évtizedes munkával sikeresen kérdőjelezték meg.
\end{abstract}

\section{Szerzó}

Imre Anikó a University of Southern California Division of Cinema and Media Studies egységének egyetemi tanára. Számos tanulmányt publikált a globális média, a (poszt)szocializmus és az identitás tárgyköreiben. Az East European Cinemas (AFI Film Readers, Routledge, 2005), a The Blackwell Companion to East European Cinemas (2012), a Transnational Feminism in Film and Media (Palgrave, 2007) és a Popular Television in the New Europe (Routledge, 2012) címú könyvek szerkesztôje; a The Journal of Popular Film and Television „Televíziós szórakoztatás az új Európában” tematikus számát (2012), az European Journal of Cultural Studies „Globális média és posztszocialista identitások” tematikus számát (2009. május); a Feminist Media Studies „Transzkulturális feminista mediációk" tematikus számát (2009. december) szerkesztette. A Palgrave-könyvek Global Cinemas címú sorozatának társszerkesztôje és több folyóirat szerkesztóbizottságának tagja.

Publikációk: Identity Games: Globalization and the Transformation of Post-Communist Media Cultures 
(MIT Press, 2009); TV Socialism (Durham, Duke University Press, 2016).

https://doi.org/10.31176/apertura.2018.3.2 


\section{Imre Anikó}

\section{Minōség és televízió}

A „minôségi televízió” fogalma magyarul ellentmondásosnak tûnik - feltételezem, hogy a legtöbb kelet-európai nyelvben úgyszintén. ${ }^{[1]} \mathrm{A}$ „minôségi” kifejezés kivételes értéket feltételez, azonban ebben a régióban a tévé kulturális és gazdasági presztízse a történelem során meglehetôsen alacsony volt. Az irodalommal, a színházzal és a mozival ellentétben a televíziót leginkább a tömegszórakoztatás és információközlés területének tekintették, nem pedig múvészeti formának. A múvészfilm, mellyel közvetlenül összehasonlítható, kulturális státuszának és relevanciájának érvényesítése érdekében masszív kritikai és oktatási infrastruktúrát épített ki. A tévével foglalkozó kutatások viszont, ha egyáltalán voltak, a szociológia és a kommunikáció területére szorítkoztak, és inkább foglalkoztak a médium társadalmi hatásával, semmint esztétikai vagy kulturális értékével.

Ez az értékhierarchia olyannyira dominánssá vált, hogy szinte magyarázkodni kell, ha a film helyzetét felmérô fórumon foglalkozunk a televízióval. Mindez a gyártási folyamatok, a részt vevô személyek, a politikai gazdaság, a terjesztési felületek, a forgalmazás és a fogyasztás szintjén végbemenô, a média oly mértékú globalizációjának, összekapcsolódásának és konvergenciájának korában történik, amikor többen is kétségbe vonták a film és a tévé megkülönböztetésének szükségességét. ${ }^{\left[{ }^{2]}\right.} \mathrm{A}$ minöségi televízió széles körû elérhetôségét - melyet csak tovább erôsítenek az internetes videomegosztó platformok - gyakran a „televíziózás végének”, a digitális kor elôtti músorsugárzás vége tünetének tekintik. Lehetséges azonban, hogy éppen ez a lényeg: akkor vált végre legitimmé a televízióról mint minôségi médiumról beszélni, amikor a televízió megszûnt tévéként létezni, saját identitását elveszítette, és különféle formákká és platformokon szóródott szét. Az általunk ismert televízió korszakának vége még könnyebbé teheti, hogy megerôsítsük a régi tévé csekély esztétikai és intellektuális értékérôl alkotott képet, a „minôségi televíziót” pedig a mozi panteonjába emeljük.

A minőségi televízió filmhez való hasonulása és abban való feloldódása sokkal gyorsabban játszódott le a közelmúltban Kelet-Európában, mint a globális médiatartalmakat gyártó angolamerikai központokban. A „minôségi televízió” nagyjából idegen fogalom maradt Európának ebben a régiójában, és leginkább olyan sorozatokra vonatkozott, amelyeket javarészt az USA-ból importáltak. A fogalom az HBO és más amerikai kábeltévé-társaságok sorozataival kapcsolódott össze, beleértve az olyan Egyesült Államok központú kábelcsatornákat, mint amilyenek a Showtime és az AMC; néhány nyugat-európai mûsorszolgáltatóval, mint a BBC; vagy a Netflix, az Amazon és a Hulu VoD [video-on-demand]-szolgáltatók néhány saját termékére utalt. Az HBO Europe helyben gyártott drámasorozatai, mint a magyar Aranyélet, a román Umbre/Arnyak, a cseh Mamon/Mammon és a lengyel Pakt/Paktum drámai formátumok laza adaptációi, vagy olyan eredeti 
múvek, amelyek helyszínhez nem kötött, transznacionális, kozmopolita érzékenységet testesítenek meg, és nemzetközi forgalomba hozatalra alkalmasak. Ahelyett, hogy a tévét a kulturális értékképzés médiumaként legitimálnák, a közelmúlt importtermékei és a kölcsönzött formátumok tovább növelhetik a távolságot a minôségi és a közönséges televízió között, és tovább mélyíthetik a mozi és a helyileg gyártott tévémúsorok minôségbeli különbségét.

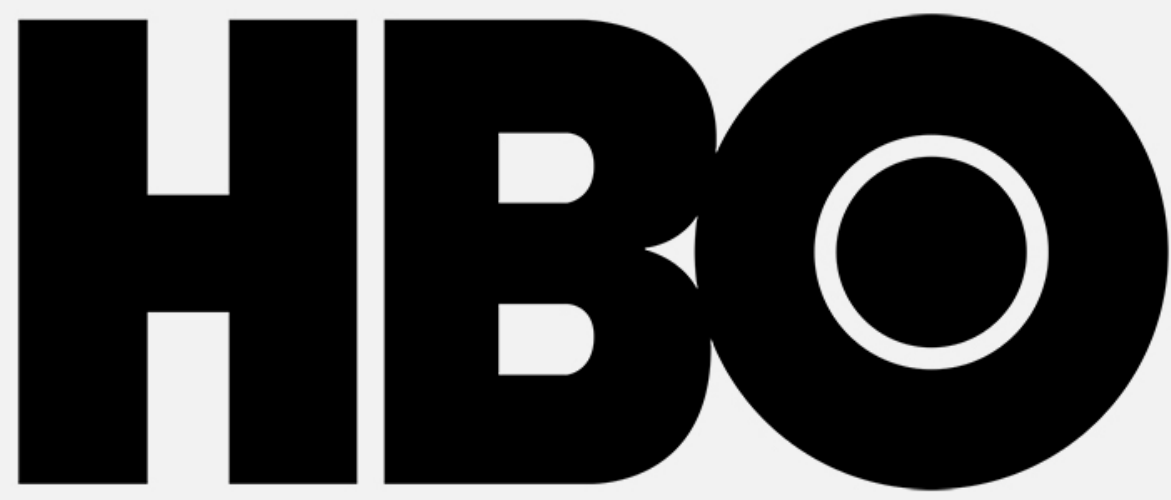

Mivel a „minőség” fogalma az utóbbi idôben a tévével kapcsolatban felbukkant, lehetôvé téve, hogy a tévé bizonyos formáit a filmmel összekapcsolva vizsgáljuk, arra is lehetôség nyílt, hogy újragondoljuk, a tévét miért utasították a figyelmen kívül hagyott, lefitymált rút kiskacsa pozíciójába egészen addig, amíg a nagy testvér, a mozi vonásait nem kezdte magára ölteni. Ez az újabb fejlemény legvégül lehetôséget nyújt arra, hogy eltávolítva [defamiliarize] megvizsgáljuk azt az értékrendet, amely szinte láthatatlanul beépült a nemzeti és a regionális kultúra szövetébe, hogy aztán vitathatatlan igazságként múködjön. Ez az értékrend igencsak szerteágazó, és a nacionalizmus, a társadalmi nem, a gyarmatosítás vagy éppenséggel a fehér faj kérdéseit is felveti: ezek a kategóriák hierarchiák alapvetését képezik, és normatív következményeik vannak a

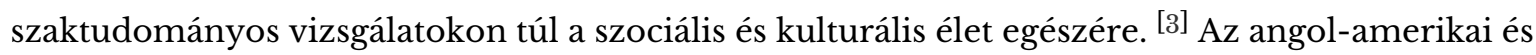
nyugat-európai országokban erre a munkára a televíziós tanulmányok [television studies] vállalkozott. (A televíziós tanulmányok az 1970-es években megjelent hibrid diszciplína, amely olyan tudományágak módszereit használta fel, mint amilyen az etnográfia, a szövegkutatás és a kultúraelmélet.) A szocialista Kelet-Európában a tévé és a hozzá kapcsolódó kutatások egészen másfajta irányt vettek. A posztszocialista évtizedek során a régió megnyílt a gyors médiaglobalizáció elôtt; az új típusú tartalmak és a múltból örökölt normatív ítéletek találkozása az értékek összezavarodását eredményezte. A minőségi televízió paradox identitása végül olyan mértékig növelte a zavart, hogy az megköveteli a probléma felbecsülését és tisztázását mind a 
televízió történetére visszatekintve, mind lehetséges jövôjére elörepillantva.

A következôkben felidézem a „minôség” különféle fogalmait, amelyek a televíziózás története során felmerültek, azokat a kulturális értékeket, amelyeket ezek a fogalmak elônyben részesítettek - és amelyeket háttérbe szorítottak -, valamint azokat a következményeket, amelyek segítenek értelmezni a „minôség felismerését” a tévében, amikor a televízió a posztszocialista régióban a filmmel konvergál.

\section{A minôségi televízió kutatása}

„Minôségi televízión” általában az Egyesült Államok hálózati korszaka utáni termékét értjük. A fogalom elsôsorban a Home Box Office prémium kábelcsatorna 1980-as évekbeli megjelenéséhez kapcsolódik, egy olyan idôszakban, amikor javában zajlott a músorszórás átalakítása, a gyártás és terjesztés új rendszerei jelentek meg, a brandingen és piaci szegmentáción alapuló széles körú gazdasági átstrukturálódás zajlott. ${ }^{4]}$ Az HBO saját marketingje a minôséget olyan eredeti kreatív vízióhoz köti, amely a szerzôi filmhez kapcsolódik. ${ }^{\left[{ }^{5}\right]}$ A szerzôi film vízióján túl a minôségi tévét definiálták még az alapján, ahogy a filmes mise-en-scène-hez és a technológiához viszonyul; [6] hogy elit közönséget szólít meg; hogy egységes a szereposztása; többsíkú, egymást átfedô cselekményszálakat használ; társadalmi és kulturális kommentárjai miatt; valamint ahogy korábbi múfajok kombinációjából hoz létre újakat. ${ }^{[7]} \mathrm{A}$ „minôségi televízió” megjelenése részben a technológiai innovációnak és a termelési érték megnövekedésének köszönhetô. ${ }^{[8]}$ A nagy felbontás, a dinamikus és gyors vágási stílus, valamint a digitális utómunka játékfilmes arculatot kölcsönöztek, és a filmrendezôket a tévéhez vonzották. A fogyasztók oldalán a nagy, széles képernyốjû digitális monitorok, amelyeket digitális és múholdas technológiák támogatnak, mozi minôségú képeket kezdtek mutatni az otthoni térben, szerte a globális piacon. Míg ezek a változások éles versenyhelyzetet és egyre inkább piaci környezetet teremtettek, a verseny felkeltette a megkülönböztethetô músorstruktúra iránti igényt. ${ }^{[9]}$

Mások úgy vélik, hogy az amerikai músorokban a minôség nem pusztán a magas termelési érték, a természetes játékmód, a precíz kameramunka és vágás, illetve a sajátos hangulatú [aural] stílus kérdése. Ezekhez hozzájárul a stiláris és tematikus egységesség is, amely elkötelezett nézői részvételt feltételez. ${ }^{[10]}$ Ezzel összhangban a minôség meghatározását kötötték továbbá - Neil Harris szavaival - az „operacionális esztétikához” is: ezek olyan textuális pillanatok, amelyek felhívják a figyelmet a narratíva konstruált voltára, és olyan pontokat hoznak létre, amelyekben a szövegszerû vonások és a nézôi élvezet találkoznak. [11]

A minôség újformalista meghatározásainak a kritikusai szerint az esztétikai jellemzôkre helyezett hangsúly kiiktatja a tartalmi és ideológiai kérdéseket, és elhomályosítja a hatalmi és politikai viszonyokat. ${ }^{[12]}$ Noha az értékelés a televízió-kutatás szükséges és viszonylag figyelmen kívül hagyott aspektusa, a „minőség” szempontjainak rögzítése óhatatlanul felvet hatalommal kapcsolatos problémákat. ${ }^{[13]}$ Felveti a kérdést, hogy ki állapítja meg a választás alapjául szolgáló 
kritériumokat, és kinek a nevében teszi. A tévéhez kapcsolt értékekkel már az 1970-es évek óta foglalkoznak kritikai, tudományos kutatások az angol-amerikai világ meghatározó országaiban. Pontosan a televízió társadalmi nemi szempontú értelmezésének relevanciája ihlette az 1970-es években a televíziós tanulmányokat, hogy új diszciplínaként kiváljon a tömegkommunikáció kutatások korlátozó kereteiből, amelyek a televízió (minden esetben káros) „hatásait” vizsgálták. Figyelemre méltó, hogy a „hatások” kutatásának normatív alapjai ellen indított lázadás motorjai feminista kutatók voltak, akik visszakövetelték a tévé nôi örömeit.

Michael Kackman amellett érvel, hogy a televíziós tanulmányok jelenlegi presztízse olyan feminista elméletíróknak köszönhetô, akik a médium alacsony kulturális értékét és lenézett örömeit a komoly kritika provokatív alapjává tették. ${ }^{[14]}$ Az HBO eredeti önmeghatározása, mely szerint az „nem televízió”, arra tett kísérlet, hogy a tévé femininizált örömeitôl elhatárolja magát, és a nagyobb presztízsú, „maszkulin”, modernista múvészethez, elsôsorban a múvészfilmhez kapcsolódjon. Az ezzel együtt járó kísérletek szintén gyanúsak, mivel újformalista alapokon elutasítják a melodramatikus stílust és a szerializációt. Kackman arra figyelmeztet, hogy a tévé legitimálása a történeti és politikai kérdésekkel foglalkozó feminista kutatás kárára történik. „Noha a legújabb tévés kutatások látszólag túlléptek a feminista médiakritikán, melyen e kutatási terület alapult, ezt gyakran úgy teszik, hogy visszatérnek azokhoz a társadalmi nemi hierarchiákhoz, amelyek miatt a médiumot a kritikusok és a nézók egyaránt megvetették." [15]

Kelet-Európában, ahol a szocialista rezsimek - mindig sikertelenül - próbálták a televíziózást az oktatás és az ideológiai kontroll maszkulinizált határain belül tartani, nem történt ehhez hasonló forradalom és újraértelmezés, a televíziós tanulmányok pedig nem fejlödött önálló kutatási területté. Ugyanilyen fontos, hogy a feminizmus a nemzeti és ideológiai kereteken belül, elkülönülten létezett, egészen a közelmúltig távol maradt a nyugati nôi mozgalmaktól és a feminizmus elméleti hullámaitól, valamint távolságot tartott a populáris kultúrától.

\section{A minôség víziói: kereskedelmi kontra közszolgálati}

A televízió az Egyesült Államokban a kezdetektôl üzleti alapokon fejlódött. Értékét elsôsorban népszerúsége alapján ítélték meg, amit nézôszámmal mértek. A háború utáni idôszakban, amikor a három fó hálózat, az ABC, az NBC és a CBS dominált, ennek az eredménye lett a „legkevésbé kifogásolható músorszerkesztés" [least objectionable programming; LOP], amelyet úgy terveztek, hogy jól bevált formákat és témákat felhasználva, a kockázatot és az innovációt pedig minimálisra csökkentve a lehetô legtöbb nézôt biztosítsák. ${ }^{[16]}$ Amitôl a LOP ódzkodott, azt hirdette a „minôségi televízió” forradalma, amelyet az 1980-as években az HBO stílusos, kifinomult, mozis eszközökkel létrehozott músorai indítottak el, és amelyek prémium kábeles elófizetéssel váltak elérhetôvé.

(Nyugat-)Európában ezzel szemben a „minôség” fogalmát hagyományosan az oktatási célú, közszolgálati televíziós csatornák által gyártott televíziós músorok számára tartották fenn. A 
háború utáni évtizedekben a televíziózást Európa túlnyomó részében a nemzeti kultúrák szolgálatába állították, a nemzeti kormányok felügyelete alatt. A nyugat-európai nemzeti tévétársaságok vagy kizárólag közszolgálati músorszórással foglalkoztak [public service broadcasting, $P S B]$, vagy egészen a közelmúltig a vegyes, közszolgálati-kereskedelmi modellt követték. A músorszerkesztés liberális modernista értékeket helyezett elôtérbe, amelyek jellemzôi a pártatlan híradás, a múveltség és a magas múvészetek, és amelyek mögött a szerzô-rendezô kreatív víziója állt. ${ }^{[17]}$ Az ilyen nagyratörô, pedagógiai célzatú kezdetek után - amelyet leginkább John Reith törekvése példáz, aki a magas kultúra tömegekhez való eljuttatását túzte ki célul - a történet már 1955-ben részben más irányt vett, amikor a BBC népszerúbb músorszerkesztési elvet kezdett követni, a kereskedelmi csatornáknál alkalmazott stratégia mintájára. ${ }^{[18]}$ Az 1980-as évekre a legtöbb nyugat-európai társaság már kettôs músorszerkesztési elvet követett: a vegyes, közszolgálati-kereskedelmi modellt.

A szocializmus idején Kelet-Európában a nemzeti televíziók nagyjából átvették a közszolgálati televíziózás értékeit, noha az ideológiai hangsúlyok eltolódtak: a BBC által felkarolt három cél közül (oktatás, tájékoztatás, szórakoztatás) a szocialista televízió leginkább az oktatást yos propagandisztikus keretben tálalta, és itikai és gazdasági liberalizmus jelentős ^ a szórakoztatást. [19]
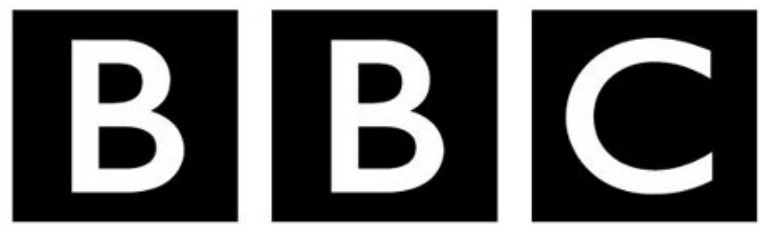

A hidegháború lezárulásával, a média gyors

globalizációjával és kereskedelmivé válásával a „minôség” fogalma Európa-szerte az amerikai televíziós drámához kapcsolódott. Az Európai Unión belül a „minôség” központi szemponttá vált a televíziózás jövôjének körvonalazásában is. Nôttt a feszültség a támogatott, de egyre inkább elavult nemzeti közszolgálati televíziós hagyomány és a globális, népszerú músorszerkesztés által bevezetett új minôségek között, amelyek gyakran mikroközönségek sajátos igényeit célozták meg. A feszültség tudományos vitákat váltott ki, és szakpolitikai változások sorát eredményezte, amelyek az európai kulturális értékek újradefiniálása körül forogtak. 
Az utóbbi húsz évben jelentôs músorpolitikai változás következett be: a „pozitív integráció” előnyben részesítését követôen, mely során kiigazították azokat a piaci erôket, amelyek a társadalmi jólétet, valamint a kulturális és politikai integrációt akadályozták, elmozdulás történt a „negatív integráció” felé, melynek célja a neoliberális piaci verseny elôtti akadályok lebontása. [20] A EU audiovizuális politikájának szabályozását indítványozó 1984-es zöld könyv egy közös európai audiovizuális tér megteremtését túzte ki célul, amelyet egymással megosztott tévéprogramok segítségével kívánt létrehozni; a nemzetek között szorosabb kapcsolatok létrejöttét szorgalmazta; terjeszteni kívánta az összeurópai örökség gondolatát, és egy közös identitás elfogadásáért szállt síkra. Más szóval a korai szakpolitika célja az volt, hogy az audiovizuális szolgáltatásokat eszközként használva kialakítsa az európai polgárokban az európai, szupranacionális identitás iránti lojalitást. A közös identitás megteremtésére helyezett hangsúly a szakpolitikai célkitúzések rákövetkezô megújításai során valamelyest háttérbe szorult, kezdve az 1997-es „Televízió határok nélkül”-irányelvtôl a 2007-es frissítéséig, az audiovizuális médiaszolgáltatásokról szóló (AVMS) irányelvig. Ezek az újabb szakpolitikai célkitúzések jellemzően a kereskedelmivé válást, a deregulációt, a médiakonvergenciát és a vállalati konglomerátumokat támogatták. Amikor a „média és digitális kultúra támogatása”, azaz az európai régióban bekövetkezô agresszív digitalizáció egyik központi területe kerül napirendre, az AVMS egyik legutóbbi frissítése „egységes megközelítést javasol a médiapolitikákat, az audiovizuális médiaszolgáltatások keretszabályozását és az európai kulturális hagyomány megôrzését illetôen”, és olyan szakpolitikákat támogat, amelyek „lehetóvé teszik az európai polgároknak, hogy zavartalan és interaktív élményekben lehessen részük, és Európa egész területén minden tartalomhoz hozzáférhessenek”. A gyakorlatban az audiovizuális és újmédia szektor számára ez közös szabályok minimumának betartására vonatkozik, amelyek hirdetésekkel kapcsolatos kikötéseket jelentenek, valamint kiterjednek európai tartalmak, a kiskorúak, a médiaszabadság, a pluralizmus és a szerzői jog védelmére. Az Európai Bizottság nemrégiben céljai közé emelte azoknak a kihívásoknak a kezelését is, amelyek álhírekhez, online dezinformáláshoz és illegális tartalmak terjesztéséhez kapcsolódnak, valamint hogy mindenki számára hozzáférhetôvé váljon a nyilvánossá tett szabad adatmegosztás, a nyílt kormányzati adatok és az európai kulturális örökség digitalizációja. [21]

Ennek szellemében az AVMS rendelet egyik legfontosabb hatása a lineáris audiovizuális médiaszolgáltatások (vagyis a hagyományos tévéközvetítés) és a „nem lineáris” szolgáltatások (vagyis a VoD-szolgáltatások) közötti különbségtétel. Ez a felosztás megfelel a szabályozás kétszintú rendszerének, amely szerint szigorúbb elốrások vonatkoznak a lineáris médiaszektorra, a nem lineáris médiaszolgáltatóknak viszont csak minimális kötelezettségei vannak. A kulturális célok tekintetében a rendelet egyértelmúen feladja a közös európai identitás ápolásának korábbi igényét, ennek helyére a kulturális sokszínúség megôrzése kerül, amit általában a nemzeti kultúrák keretei között értelmeznek. ${ }^{[22]}$ 
Bár az Egységes Digitális Piac stratégiái a végrehajtás korai szakaszában vannak, máris nyilvánvaló, hogy az irányelv a kis nemzeti piacokat különösen sérülékennyé teszi a médiaglobalizáció és a konglomerátumok hatalmával szemben, és rendkívül kevés szabadságot ad a saját médiastratégia kialakítására, gyakorlatilag a saját helyi piacok fenntartására szorítják ôket. ${ }^{[23]} \mathrm{Ez}$ a logika együtt jár a fokozódó nacionalista elzárkózással; ebben az értelemben a médiapolitika, ahelyett, hogy egy nemzetek feletti identitást alakított volna ki, inkább Európa növekvő megosztásához járult hozzá.

\section{HBO: konvergáló minôségek}

A növekvő médiakonglomerátumoknak és a digitális terjesztésnek köszönhetôen - amelyeket szintén erôsít az EU-s médiastratégia - érezhetô piaci konvergencia alakult ki a történelmileg egymástól eltérô európai közszolgálati és az amerikai HBO típusú „minôségek” között. A minôségek konvergenciájának egyik aspektusa a film és a televízió közötti hagyományos megkülönböztetés megszúnése volt. Manapság ritka, hogy a rendezők, forgatókönyvírók és producerek karrierjüket kizárólag a filmre vagy a televízióra építenék. Európában a filmek finanszírozása egyre inkább függ a tévés jogok elôzetes eladásától. A közszolgálati tévétársaságokban dolgozók munkakörülményeit - a filmipar mintájára - egyre inkább a nem állandó munkaviszony, a bizonytalanság és a kiszervezés jellemzik. A „minôségi televízió” egyfajta gyújtôfogalommá válik, amelybe (a filmre és a közszolgálati televíziózásra egyaránt vonatkozó) témák, stílusok, ipari gyakorlatok, termelési minôségek és tehetséges alkotócsoportok egyaránt beletartoznak. ${ }^{[24]}$

Ennek a konvergenciának a legjobb példája az HBO, amelynek sikerült különleges helyet kivívnia a zsúfolt európai tévépiac számtalan versengô földfelszíni, kábeles és online tartalomszolgáltatása között. Szinergia van az Európai Unió kulturális és gazdasági stratégiái között, amelyeket úgy képzeltek el, mint identifikációk mozgékony, alkalmazkodó adatbázisát (a párhuzamosan elérhetô nemzeti, regionális, európai és globális csomópontok között), másrészrôl pedig az uniós médiaszabályozási alapelvek között, amelyek a határok nélküli, digitális szolgáltatásokat részesítik elônyben, mivel azok a transzeurópai és a globális léptékben is múködôképesek, és a kifinomult, kozmopolita európai fogyasztó számára választható músorok széles palettáját nyújtják. Az HBO iskolapéldája ennek a kulturális, gazdasági és szabályozási közegnek. Kiváló minôségú filmjeinek és tévémúsorainak sora videomegosztó platformokon keresztül az EU szinte teljes területén hozzáférhetô; minôségi mûsorok kölcsönzésére, eredeti drámasorozatok és dokumentumfilmek készítésére szakosodott, és a transznacionális esztétikai érzékenységet olyan témákkal és múfajokkal ötvözi, amelyek országokon átívelô érdeklôdésre számíthatnak, viszont mindezek helyi kérdések aspektusából kerülnek bemutatásra.

Az HBO márka identitása különösen megfelel Európa központi országai számára, ahol a város és vidék közötti szakadék nem olyan hatalmas, a széles sávú lefedettség magasabb, ${ }^{[25]}$ és az HBO minôségi músorszerkesztése és a progresszív célokba való önzetlen befektetései szervesen épülnek 
be, és együttmúködnek a közszolgálati mû́sorszórás erôs hagyományaival. [26]

A kelet-európai régióban, ahol a közszolgálati média posztszocialista fejlődése megrekedt, részben az HBO kezdte elfoglalni azt a teret, amelyet az erôsebb demokratikus hagyománnyal rendelkező országokban a közszolgálati músorszórás töltött be. ${ }^{[27]}$ Mára vitathatatlan tény, hogy az EU-hoz 2004 óta csatlakozó tíz országban az átmeneti idôszak máig nem hozta el azt a politikai és gazdasági liberalizációt, amelyben az optimisták reménykedtek. Az utóbbi években ehelyett a külföldi médiabefektetôk fokozatosan kivonultak, és a helyi gazdasági elit erôsödô befolyásra tett szert a hírmédia szektorban. ${ }^{[28]}$ A nyugati típusú médiaipar drasztikus visszaszorulásának részben kétségtelenül a gazdasági recesszió az oka. A nyugatias médiaipar visszaszorulásának azonban fontosabb oka a széles körú politikai korrupció által meghatározott kedvezôtlen üzleti környezetre adott közös válasz, valamint a politikai összefonódások megjelenése a piaci versenyben, amelynek mozgatói olyan médiaipari oligarchák, akik médiabirodalmukat politikai vagy pénzügyi érdekeik érvényesítésére használják fel. [29]

Ebben a környezetben az HBO lokális gyártási modellje lehetôvé tette a helyi tehetségek számára, hogy a befogadó intézménytôl többé-kevésbé függetlenül, saját anyanyelvükön készítsenek sorozatokat transznacionális témákra reflektálva vagy azokat adaptálva, és olyan történeteket mondjanak el, melyek nemzeti és regionális szinten nagy érdeklódésre számíthatnak. Bár az HBO leginkább a városi nézôk között népszerû, a legutóbbi adaptációk és eredeti sorozatok szélesebb közönséghez szólnak, mivel ismerôs, helyi történeteket és karaktereket használnak fel, elérhető áron kínálják a szolgáltatást, és nem követelnek meg idegennyelv-tudást. Az HBO drámák transznacionális esztétikája, magas gyártási értéke és filmes minôsége a magasmúvészet iránti kulturális preferenciát elégíti ki, amely a régió kulturális nacionalizmusának sarkalatos pontjává vált. Mivel Agnieszka Holland rendezte az Olthatatlant (Horici ker, 2016), a cseh HBO eredeti sorozatát, az Oscar-jelölt Enyedi Ildikó rendezte a Terápia (Gigor Attila, Enyedi Ildikó, 2012) magyar adaptációját, vagy $A z$ árnyak címú román sorozatot Bogdan Mirica jegyzi, aki 2016-ban megkapta a Cannes-ban a Filmkritikusok Nemzetközi Szövetségének díját Kutyák címú játékfilmjéért, ezek a produkciók azonnal kitûnnek a hétköznapi tévémúsorok közül. ${ }^{[30]}$ Noha a múvészfilmekhez hasonlóan elit közönséghez szólnak, ugyanakkor az HBO minőségi drámái és dokumentumfilmjei szélesebb közönséget kívánnak megszólítani - egyfajta minőségi, szórakoztató esztétikát hoznak létre hétköznapi nyelven, amely korábban nem létezett, mivel a múvészfilm és a tévé között értékbeli szakadékot feltételeztek. 


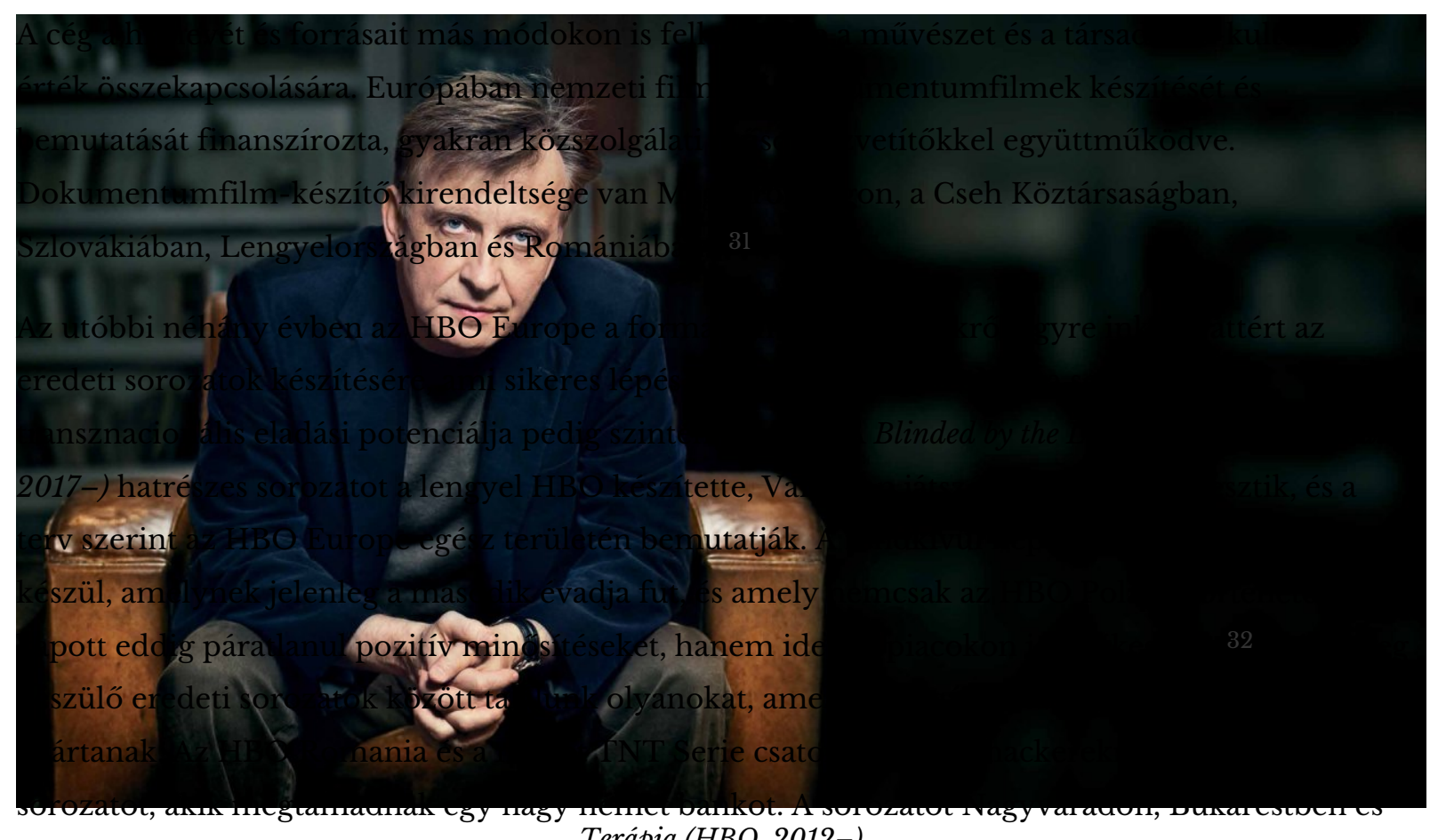

Frankfurtban tervezik forgatni, a producer pedig a nagy tiszteletnek örvendô román újhullámos rendező, Cristian Mungiu. A szereplőgárda nemzetközi, és összetétele a sorozatban ábrázolt aktuális európai búnszövetkezetekét tükrözi. A produkció folytatja a kreatív filmes és tévés tehetségek interregionális foglalkoztatásának történelmi hagyományát. [33]

Az HBO abból a szempontból is hiánypótló szerepet tölt be, hogy transznacionális médiavállalatként kikerül a közvetlen kormányzati cenzúra és kontroll alól. ${ }^{[34]}$ Ezáltal a helyileg készített músorok megtehetik, hogy visszafogott társadalmi-politikai kritikát is megfogalmazzanak, ami megritkult, vagy éppenséggel eltûnt a legtöbb posztszocialista országban. A helyileg gyártott HBO drámasorozatok felismerhetô nemzeti karaktertípusokat és ismerôs narratívákat mutatnak be arról a hosszú idôszakról, amely a szocializmusból a kialakuló neoliberális kapitalizmusba való átmenet korrupt körülményeit jellemzi. Például mind az Arnyak, mind az Aranyélet fôszereplôje köznapi ember, akik a gazdagság reményében kezdenek illegális üzleti tevékenységet. Amikor megpróbálnak véget vetni a bünözésnek, csak még jobban belegabalyodnak; a sorozatok így folyamatában láttatják a megkerülhetetlen kormányzati és üzleti korrupciót. Realista, kortárs karakterek és beszédstílus alkalmazásával, a múvészfilmek elitista megszólalásmódjától eltávolodva, az HBO-nak sikerült közvetlenebb módon bemutatni a kezelhetetlen korrupció témáját. [35]

A korrupció által ihletett történet, amely a kortárs transznacionális krimi múfajának középpontjában áll, manapság világszerte könnyen lefordítható helyi viszonyokra. Olyan témáról van szó, amely az intézményekbe vetett hit globális válságára irányítja a figyelmet - legyen szó az Európai Unióról, nemzeti kormányokról vagy társulatokról, ahogy ezt például a European Journal of Communication 2018-as, korrupcióról szóló különszáma és a szám európai médiavisszhangja bizonyítja. ${ }^{[36]}$ Az intézményes korrupció csápjai a krimikben mindenhová elérnek; ez lehetôvé teszi, hogy ennek révén strukturálisan idézzék meg a digitális felügyelet tapasztalatát, a big data 
fenyegetését, a globális piacok ingadozását, a küszöbön álló környezetvédelmi katasztrófát és a tekintélyelvú populizmus terjedését világszerte. Nem csoda, hogy az eredetileg egy norvég közszolgálati tévécsatorna, az NRK1-nek gyártott Mammon (2014, 2016), mint az „északi noirként” vagy „skandináv noirként” [Scandinoir] ismert minőségi krimigyártás újabb sikeres produktuma (mely egy újságíróról szól, aki felfedi a fivére által vezetett cég korrupcióját), két kelet-európai HBO adaptációt is megihletett, egyet a Cseh Köztársaságban, a másikat pedig Lengyelországban.

Az HBO Europe árnyaltan érzékeli a korrupciót, amely a neoliberális kapitalizmus elsöprô globális sikerének nyomán keletkezett kiábrándulást veszi körül, foglalkozik a neoliberális kapitalizmus válságának európai, kontinentális változatával, valamint a cinizmus és elkeseredettség helyi tapasztalatával, melyet a posztszocialista perifériák kis nemzetei tapasztalnak, ahol a lakosság különösen hajlamos visszavonulni a defenzív populista nacionalizmusba. A Mammonban a korrupció némileg különválasztható az üzleti és politikai élet rendes múködésétôl, és bátor oknyomozó újságírók rántják le róla a leplet, akik végsô soron a demokrácia és az átláthatóság erôs hagyományára támaszkodnak. Olaszországban, abban az európai államban, ahol az intézményes korrupció talán a leghosszabb múltra tekint vissza, nagy sikereket arattak a közelmúltban készült, korrupciót és antihősöket bemutató minôségi sorozatok, mint amilyenek a Gomorrah (Sky Italia, 2014-), a Suburra (Netflix, 2017-) és a Romanzo Criminale (Sky Cinema, 2008-2010). [37]

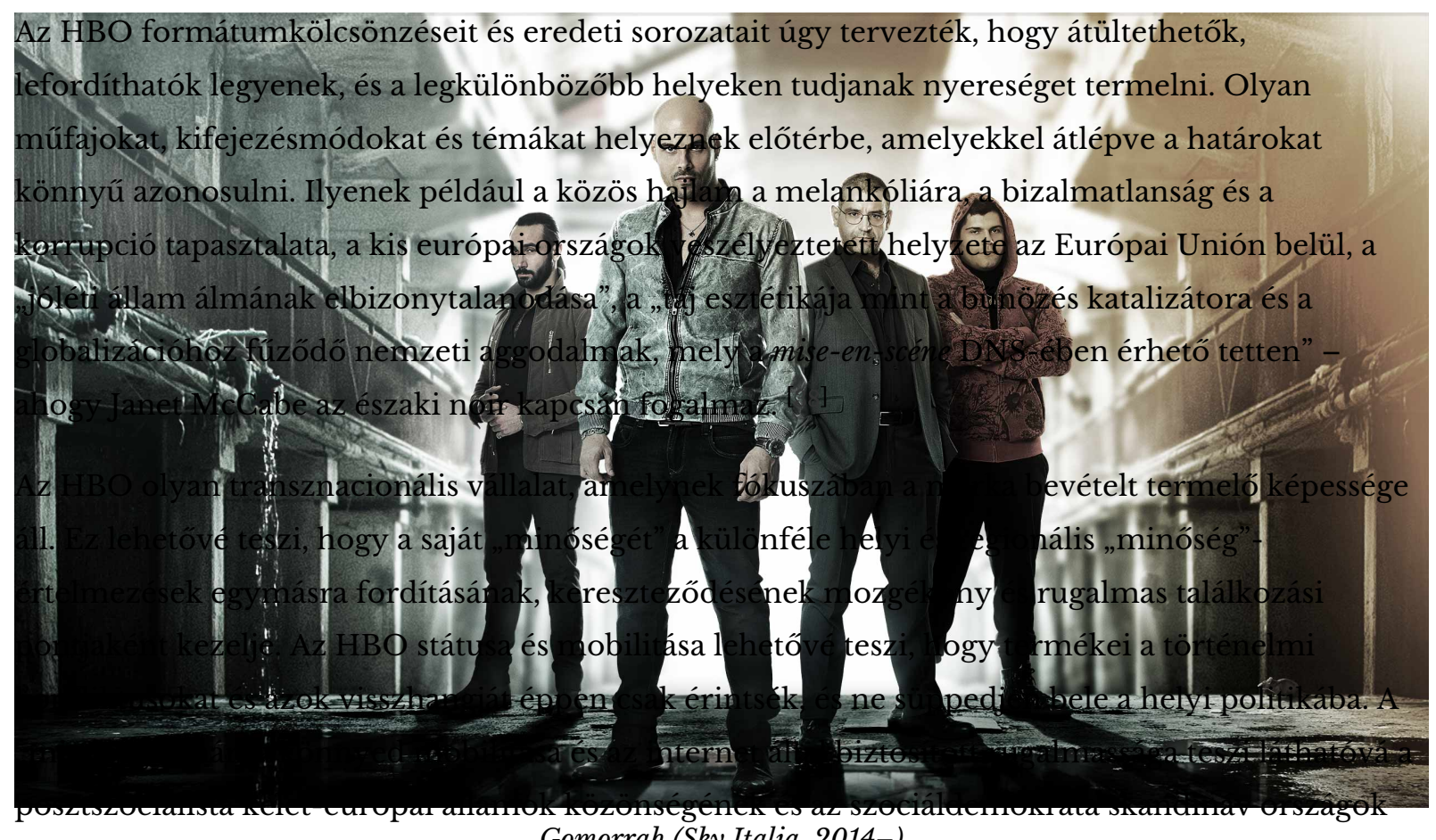

kis nemzeteinek ízlésbeli hasonlóságat - a komah (Sky Italia, 2014-) politikai megosztottság árnyékában ezek a párhuzamosságok egyébként nem lettek volna láthatók.

Az HBO „minőségi tévéje” által létrehozott hibrid létesítmény fából vaskarika, és olyan témákat vet fel, amelyek messze túlmutatnak a filmnek és a televíziónak értékek, módszerek és intézményi 
infrastruktúrák mentén történô hierarchikus megkülönböztetésén. Az HBO sikeresen lebontotta (vagy megkerülte) a nemzeti és a nemzetek fölötti identitással való azonosulás látszólag áthidalhatatlan szakadékát. Létrehozott és elterjesztett egy összeurópai megközelítést, amely a maga rugalmas „minôségi” brandjével átfogja a közszolgálati televíziózás, a múvészfilm és a dokumentumfilm európai hagyományát, és olyan történeteket, témákat, karaktereket és stílusokat kínál, amelyek az adott nemzeti kontextusban „eredetinek” minôsülnek, ugyanakkor könnyen átvihetôk egyik piacról a másikra, mivel közösen osztott európai és globális narratívákon alapulnak, amelyek az internetes terjesztés digitális platformjainak köszönhetően még inkább összekeveredtek.

\section{Záró következtetések}

A minôségi tévé megjelenése, aminek a leginkább befolyásos változatát az HBO képviseli, szükségessé teszi, hogy reflektáljunk a tisztán esztétikainak gondolt kritériumok ideológiai és etikai alapjaira, amelyek fenntartják a múvészfilm és a televízió közötti hierarchikus megkülönböztetést. Azért is válik mindez szükségessé, mert megjelenik az ipari brand által meghatározott kereskedelmi érték kísértete, és megkérdôjelezi azt az elképzelést, hogy a közös ízlésen osztozó közönségcsoportok meghatározott kulturális formák mentén alakulnak ki, és hogy ezek az ízléscsoportok egyáltalán elhatárolhatók nemzeti alapon.

Az HBO múködése nyilvánvalóvá teszi az európai kulturális és üzleti térben múködô cserefolyamatok mértékét, valamint a nemzeti, intellektuális felügyeletet, amely alulbecsülte az európai médiák összekapcsolódását a predigitális korban. A kelet-európai kulturális nacionalizmusoknak voltaképpen mindig is kulcsfontosságú eleme volt a kozmopolitizmus. A múvészek, a történetek és a közönségek mindig is az európai körforgás részei voltak. A szocialista film és televízió kiterjedt európai hálózatoknak volt a része - akár hivatalos, akár nem hivatalos hálózatokról van szó. ${ }^{[39]}$ Az HBO és más médiatársaságok ezekre a meglévő transznacionális hálózatokra és együttmúködési hagyományokra építenek, és ezekból profitálnak.

Ha ezt a logikát visszamenôleg is alkalmazzuk, amellett érvelhetünk, hogy a múvészfilmhez társított esztétikai minôséget a piaci értéke határozta meg, mely a nemzetközi terjesztés során alakult ki. Más szóval a múvészfilm nemzeti értékét pontosan a kozmopolita európai és globális színtéren való nemzetközi érvényesülése határozhatja meg, nem pedig fordítva. Ez a nemzeti értéket függônek, tranzakciósnak mutatja, semmint inherensnek és változtathatatlannak. Ez a tranzakciós érték tehát nem pusztán esztétikai, hanem óhatatlanul gazdasági is, hasonlóan a minôségi televízióhoz.

Ehhez hasonlóan a minôségi televízió megkérdôjelezi a tévé közönségérôl kialakult leegyszerúsítô és egynemú nézetet, miszerint az „emberek” (a szólás szerint) hozzá vannak ragadva a tévéképernyoóhöz. Az angol-amerikai kontextusban a televíziós tanulmányok egyik legfontosabb lépése az volt, hogy megszüntette a tévéhez és valamilyennek kikiáltott közönségéhez kapcsolódó 
„búnös élvezet” vagy „szemét” stigmákat, és sokkal árnyaltabban mutatta be a televízió által betöltött társadalmi és kulturális közvetítés feladatát. Ezt a folyamatot, amely során a televíziót kulturális tôkével ruházták fel, a televízió tanulmányozása pedig legitimmé vált, nagyban befolyásolták a kritikai kultúrakutatás belátásai. A kritikai kultúrakutatás lényegét tekintve interdiszciplináris módszer, amely rámutatott az esztétikai és politikai reprezentáció közötti ideológiai összefüggésekre, és megkérdôjelezte a magas- és populáris kultúra közötti határvonalakat. Leginspirálóbb szövegeiben, például Raymond Williams munkáiban - aki a kritikai kultúrakutatás egyik alapító figurája és szövegei a televíziós tanulmányok igen fontos forrásai -, a kritikai kultúrakutatás kitartóan mutatta be, honnan származik a reprezentációs rendszerek társadalmi és politikai ereje. Egy 1984-ben írt munkájában, melyben a kritikai kultúrakutatás jelentôségérôl és irányáról szóló vitához szólt hozzá, és amely The Uses of Cultural Theory címet viseli, Williams úgy érvel, hogy a kultúraelmélet akkor a leghasznosabb, amikor egyaránt elkerüli a múvészetre jellemzô formalista megközelítést és a szociológiai kritikát, amelyet a populáris kultúra tárgyainak és szövegeinek értelmezésére tartanak alkalmasnak. A kritikai kultúrakutatás ehelyett arra hívja fel a figyelmet, hogy mindkét módszer saját, természetesnek tekintett kategóriái elrejtik a történelmi, társadalmi és politikai struktúrákba való beágyazottságukat. [40]

Az utóbbi évtizedekben felbukkant önprezentációs gyakorlat, hogy az ipar „nem tévének” minősíti a minôségi televíziót, a televíziós tanulmányok szakemberei számára magát a televíziót mint a társadalmi jelentésért vívott azon ideológiai küzdelem színterét veszélyezteti, melyre a televíziós tanulmányok hívták fel a figyelmet. A minôségi televízió azzal fenyeget, hogy újformalista módon újraesztétizálja a televíziót, és zárójelbe teszi az ideológiai és kulturális kérdéseket, azokra az auteurdiskurzusokra támaszkodva, amelyek a filmtudományból maradtak fenn. Sudeep Dasgupta rámutat arra, hogy a televíziós tanulmányok minôségi tévé általi fenyegetettsége arra sarkallt egyes kutatókat, hogy átessenek a ló túloldalára: a televíziónak a múvészfilmbe való újformalista asszimilációjának elutasításával egyben lemondtak az esztétikai és textuális elemzésrốl is. Dasgupta arra figyelmeztet, hogy az ilyen meggondolatlan reakció kiváltója a köznapi, nem minőségi tévé „emberérôl” alkotott romantikus kép, akik nevében a televíziós tanulmányok kutatói szembeszegülnek azzal, hogy a minôségi tévé visszaállítson egy hierarchikus értékrendet. Ez az ellenállás azonban esszencialista elôfeltevéseken alapul, amelyek a szövegeket, nézôket és a médiumot esszencialista, paternalista módon rendezik újra, hasonlóan ahhoz, ahogy a minőségi tévé marketingstratégiái múködnek. ${ }^{[41]}$

Dasgupta úgy kívánja visszanyerni az esztétikai elemzést, mint amely nem eleve „elitista, apokaliptikus vagy egyszerūen a tôke felhalmozásának a stratégiája; politikai, mivel reprezentációs rendszereket és azok viszonyát vizsgálja a társadalmi formációk kialakulásához. Feminista, posztkoloniális, queer és egyéb értelmiségi írások évtizedeken keresztül komolyan vették a reprezentációs stratégiák esztétikáját, mint annak módozatát, ahogy a társadalmi hatalom egyszerre fenntartható és kikezdhetô. A televíziós tanulmányok mint diszciplína maga is jelentôs elemzéseket hozott létre ezeken a területeken, azonban amint szóba kerül a "minôségi televízió» 
kérdése, az esztétikai elemzés vagy határtalanná válik [...] vagy problémássá [...].”

A televíziós tanulmányok elôtt álló kihívás az, hogy újrapolitizálja az esztétikát, hogy hangsúlyozza a reprezentációs rendszerek elemzésének politikai fontosságát. A kelet-európai régióban, ahol a televíziós tanulmányok és a kritikai kultúrakutatás hatása nem volt jelentôs, a kihívás bizonyos szempontból éppen az ellenkezője: nem szabad a minôségi televíziót a múvészfilm és az irodalom számára fenntartott, messzemenôen apolitikus esztétikai elemzés tárgyává tenni és a köznapi tévé halálát szerencsés megszabadulásként értelmezni. Ez annak a lehetôségnek az elszalasztását jelentené, hogy megkérdôjelezzük azokat a kategóriákat, amelyek az esztétikai elemzést a reprezentáció politikáján kívülre helyezik. Ez veszélyes felvetés, különösen akkor, amikor tombol a populizmus, és a meghatározó politikai közbeszéd szintjén folyamatosan támadják az intellektuális „elitizmust” és a kritikus oktatást. Ennél produktívabb válasz lehet a minôségi tévére a hierarchikus előfeltevések elitista, esztétikai módszerétôl eltávolodott oktatás és tudományos kutatás aktív újralegitimálása, legalábbis Raymond Williams javaslatát követve, aki szerint a kultúraelmélet célja, hogy a társadalmi jelentés és az esztétikai reprezentáció módjai között közvetítsen, és erôsítse a közöttük lévô hatást.

A minőségi televízió áthelyezi és összekeveri azokat a diszciplináris és módszertani apparátusokat, amelyeket általában különállókként képzelünk el. A (film)esztétika és -történet nehezen egyeztethetô össze olyan tudományokkal, amelyek médiapolitikával, technológiával és iparral vagy fogyasztással, nézőséggel és a rajongók közösségeivel foglalkoznak; utóbbiak viszont általában nem foglalkoznak identitással, nacionalizmussal, idegengyúlölettel, rasszizmussal és kozmopolitizmussal. Úgy túnik, az esztétika, a közönségek, a szakpolitikák és a politika kutatása módszertanilag összeegyeztethetetlen, ami megnehezíti ideológiai összefonódásaik belátását. Végül is a minőségi tévé azt követeli meg tôlünk, hogy lebontsuk ezeket a határokat, és számba vegyük, hogyan támogatjuk a szétválasztottságokat fenntartó értékeket.

Fordította Matuska Ágnes A fordítást ellenôrizte Török Ervin

\section{Jegyzetek}

1. Talán ezért van az, hogy a minôségi drámasorozatokra utalva a „tévé” jelzô helyett egyszerúen „film” áll. Lásd például a Virginás Andreával készített interjút a Kolozsvári Rádió Sajtóklub músorában, 2018. június 11. http://kolozsvariradio.ro/2018/06/12/sajtoklub-tevesorozatok-folytatasos-filmek-felsofokon/

2. Caldwell, John: Production Culture: Industrial Reflexivity and Critical Practice in Film and Television. Durham, NC, Duke University Press, 2008. 9.

3. Legitimating Television (New York, Routledge, 2011) címú kötetükben Michael Z. Newman és Elana Levine amellett érvelnek, hogy az amerikai „minôségi televízió” legitimációját „társadalmi osztályok, társadalmi nemek, társadalmi pozíciók hierarchiái” teszik lehetôvé, amelyek ösztönzik a televízió legitimálását, és „az 
ízlés és a hatalom zálogává teszik az új aranykorról szóló diskurzus prezentista elképzeléseit.” (17.)

4. McCabe, Janet és Kim Akass: Introduction: debating quality. In Janet McCabe és Kim Akass (szerk.): Quality Television: Contemporary American Television and Beyond. I.B. Tauris, London, 2007. 3.

5. McCabe, Janet és Kim Akass: Sex, Swearing and Respectability: Courting Controversy, HBO's Original Programming and Producing Quality TV. In Quality Television, 2.

6. Bignell, Jonathan: Seeing and knowing: reflexivity and quality. in Quality Television, 158-170.

7. Thompson, Robert J.: Television's Second Golden Age: From Hill Street Blues to ER. Continuum, New York, 1996. 12-16.

8. Nelson, Robin: Quality TV drama: estimations and influences through time and space. In Quality Television , 38-51. (43.); Meinhof, Ulrike: Worlds in Common? Television Discourse in a Changing Europe. Routledge, London, 1999. 71.

9. Ulrike Meinhof: i. m. 49.

10. Cardwell, Sarah: Is quality television any good? Generic distinctions, evaluations and the troubling matter of critical judgement. In Quality Television: Contemporary American Television and Beyond, 19-34. (30-31.

11. Kackman, Michael: Quality television, melodrama, and cultural complexity. Flow, 2008. október 31. http://flowtv.org/?p=2101\#printview.

12. Fricker, Karen: Quality tv' on show. In Quality Television, 13-16.

13. Brunsdon, Charlotte: Problems with quality. Screen, 1990, 31. 1. 67-90.

14. Kackman: i. m.

15. Kackman: i. m.

16. Nelson: i. m. 38 .

17. Nelson: i. m. 39.

18. Nelson: i. m. 40.

19. Errôl részletesebben lásd Imre Anikó: TV Socialism. Durham, Duke University Press, 2016.

20. Klimkiewicz, Beata: Introduction: Harmonizing European Media Policy. Supranational Regulatory Trends and National Responses. In Beata Klimkliewicz (szerk.): Media Freedom and Populism: Media Policy Challenges in the Enlarged Europe. CEU Press, 2013.

21. Digital Single Market Policy: Supporting Media and Digital Culture. URL: https://ec.europa.eu/digitalsingle-market/en/policies/supporting-media-and-digital-culture. A magyar változat elérhető itt: https://eur-lex.europa.eu/legal-content/HU/TXT/HTML/?uri=CELEX:32010L0013\&from=EN

22. Štetka, Václav: Struggling with Diversity: Objectives, Outcomes, and Future of the European Quota Policy in the Context of the Television Scene in the Czech Republic. In Media Freedom and Populism

23. Szczepanik, Petr: Localize or Die: Intermediaries in a Small East-Central European On-Demand Market. Cinéma छ Cie, 2017. ôsz, XVII. 29.

24. Szczepanik, Petr: Post-socialist producer: The production culture of a small-nation media industry. In Critical Studies in Television, 13. 2, 207-226.

25. Europe's Digital Progress Report, European Commission, Digital Single Market, 2017. URL: https://ec.europa.eu/digital-single-market/en/news/europes-digital-progress-report-2017

26. Lásd például Clover, Julian: HBO and Sky in 250 Million Drama Agreement. Broadband TV News, 2017. április 20. URL: https://www.broadbandtvnews.com/2017/04/20/hbo-and-sky-in-250-million-dramaagreement/

27. A kelet-európai régióban a cseh közszolgálati televízió valamelyest kivételnek számít azzal, hogy elkötelezte magát a közszolgálati média hagyománya mellett, például a nemzeti közönség számára 
készített új sorozatok készítésével és a nemzeti filmes örökség megórzésével. Lásd Szczepanik 2017.

28. Štetka, Václav: From Multinationals to Business Tycoons: Media Ownership and Journalistic Autonomy in Central and Eastern Europe. The International Journal of Press/Politics, 2012. 17.4. 433-456.

29. Štetka: i.m. 441-42.

30. Roxborough, Scott: HBO Europe: The Best TV You've Never Seen. The Hollywood Reporter, 2017. november 16. URL: https://www.hollywoodreporter.com/news/hbo-europe-best-tv-youve-never-seen1048497.

31. Stewart Clarke: IDFA: Young Directors at Forefront of HBO Europe's Documentary Slate. Variety, 2017. november 17. URL: http://variety.com/2017/tv/news/idfa-hbo-young-directors-europe-documentaryslate-1202617322/.

32. Dziadul, Chris: HBO Starts Polish Productions. Broadband TV News, 2016. november 24. URL: https://www.broadbandtvnews.com/2016/11/24/hbo-starts-polish-productions/

33. Cristian Mungiu a producere a Romaniai Hackerekrôl Szóló ÙJ HBO Sorozatnak. Filmtett, 2018. február 17. URL:

34. Soós Tamás Dénes: Aranyélet jobban teljesít. Filmvilág, 2016/2. URL: http://filmvilag.hu/xista_frame.php?cikk_id=12577.

35. Soós: i.m.

36. European Journal of Communication, 33.1. 2018. Szerk. Paolo Mancini.

37. Ferrari, Chiara workshop-elôadása. Society for Cinema and Media Studies konferencia, Toronto, 2018. március

38. McCabe, Janet: Review article of Steven Peacock. In Swedish Crime Fiction: Novel, Film, Television, Manchester, Manchester University Press, 2014. és Eva Novrup Redvall: Writing and Producing Television Drama in Denmark: From The Kingdom to The Killing. Basingstoke, Palgrave Macmillan, 2013. Critical Studies in Television, 2016, 11.1, 119-122.

39. Lásd Imre, Anikó: i.m.

40. Williams, Raymond: The Uses of Cultural Theory. New Left Review, 1. 1985. 19-31.

41. Dasgupta, Sudeep: Policing the People: Television Studies and the Problem of 'Quality'. NECSUS Journal, 2012. tavasz. URL: https://necsus-ejms.org/policing-the-people-television-studies-and-the-problem-ofquality-by-sudeep-dasgupta/\#_edn22.

\section{Irodalomjegyzék}

- Brunsdon, Charlotte: Problems with quality. Screen, 1990, 31. 1. 67-90.

- Caldwell, John: Production Culture: Industrial Reflexivity and Critical Practice in Film and Television . Durham, NC, Duke University Press, 2008. https://doi.org/10.1215/9780822388968

- Dasgupta, Sudeep: Policing the People: Television Studies and the Problem of 'Quality'. NECSUS Journal, 2012. tavasz. URL: https://necsus-ejms.org/policing-the-people-televisionstudies-and-the-problem-of-quality-by-sudeep-dasgupta/\#_edn22.

- European Journal of Communication, 33.1. 2018. Szerk. Paolo Mancini.

- Imre Anikó: TV Socialism. Durham, Duke University Press, 2016.

- Kackman, Michael: Quality television, melodrama, and cultural complexity. Flow, 2008. október 31. http://flowtv.org/?p=2101\#printview.

- Klimkiewicz, Beata: Introduction: Harmonizing European Media Policy. Supranational 
Regulatory Trends and National Responses. In Beata Klimkliewicz (szerk.): Media Freedom and Populism: Media Policy Challenges in the Enlarged Europe. CEU Press, 2013.

- McCabe, Janet és Akass, Kim(szerk.): Quality Television: Contemporary American Television and Beyond. I.B. Tauris, London, 2007.

- McCabe, Janet: Review article of Steven Peacock. In Srwedish Crime Fiction: Novel, Film, Television , Manchester, Manchester University Press, 2014.

- Meinhof, Ulrike: Worlds in Common? Television Discourse in a Changing Europe. Routledge, London, 1999.

- Novrup Redvall, Eva: Writing and Producing Television Drama in Denmark: From The Kingdom to The Killing. Basingstoke, Palgrave Macmillan, 2013. https://doi.org/10.1057/9781137288417

- Roxborough, Scott: HBO Europe: The Best TV You've Never Seen. The Hollywood Reporter, 2017. november 16. URL: https://www.hollywoodreporter.com/news/hbo-europe-best-tvyouve-never-seen-1048497.

- Soós Tamás Dénes: Aranyélet jobban teljesít. Filmvilág, 2016/2. URL: http://filmvilag.hu/xista_frame.php?cikk_id=12577.

- Stetka, Václav: From Multinationals to Business Tycoons: Media Ownership and Journalistic Autonomy in Central and Eastern Europe. The International Journal of Press/Politics, 2012. 17.4. 433-456.

- Szczepanik, Petr: Localize or Die: Intermediaries in a Small East-Central European OnDemand Market. Cinéma \& Cie, 2017. ôsz, XVII. 29.

- Szczepanik, Petr: Post-socialist producer: The production culture of a small-nation media industry. In Critical Studies in Television, 13. 2, 207-226.

- Thompson, Robert J.: Television's Second Golden Age: From Hill Street Blues to ER. Continuum, New York, 1996.

- Williams, Raymond: The Uses of Cultural Theory. Nerw Left Revierw, 1. 1985. 19-31.

\section{Filmográfia}

- Azárnyak (Umbre. HBO, 2014-)

- Blinded by the Lights (Slepnac od Swiate. 2017-)

- Gomorrah (Sky Italia, 2014-)

- Kutyák (Câini. Bogdan Mirica, 2016)

- Mammon (HBO, 2015-)

- Olthatatlan (Horici ker. HBO, 2013-)

- Romanzo Criminale (Sky Cinema, 2008-2010)

- Suburra (Netflix, 2017-)

- Terápia (HBO, 2012-) 
(C) Apertúra, 2018. tavasz | www.apertura.hu

webcím: https://www.apertura.hu/2018/tavasz/imre-minoseg-es-televizio/

https://doi.org/10.31176/apertura.2018.3.2

Apertura.hu

Image not found or type unknown 